\title{
Attachment Relationships with Fathers and Mothers during Early Chilhood
}

\author{
Nerea Portu-Zapirain \\ University of the Basque Country, San Sebastian, Spain \\ Email: nerea.portu@ehu.es
}

Received December $18^{\text {th }}$, 2012; revised January $11^{\text {th }}$, 2013; accepted February $16^{\text {th }}, 2013$

\begin{abstract}
The aim of this study was to analyze the nature of affective relationships between parents and children and to explore representational models in a sample of 111 children aged between 3 and 6, assessed using a projective measure. The results obtained confirm that, globally, security in the representation of attachment is higher with mothers. The figure of the father in the established hierarchy is secondary. The results also reveal a statistically significant relationship between children's age and the attachment established with their fathers and mothers. The older the child, the greater the security manifested in their relations, and the younger the child, the greater the insecurity.
\end{abstract}

Keywords: Representational Models of Attachment Relationships; Attachment Relationships with Fathers and Mothers; Early Childhood

\section{Introduction}

The significance of attachment theory (Ainsworth, 1973; Bowlby, 1969, 1980), considered one of the most important theoretical and empirical constructions in the field of socioemotional development, is based on the formulation of internal working models of oneself and one's relationships, in close connection with behaviors and feelings.

Models reflect the construction of a mental representation of the world, based on the generalization of the interactions children experience with their attachment figures during their early relations with the adults that satisfy their needs, and include the internalization of specific attributes and expectations of both their own behavior (feeling loved, accepted and protected) and the behavior their attachment figures. They also constitute a pattern for the relationships that individuals will then establish throughout the rest of their lives. Once set, these patterns tend to become more consistent and inflexible, with a strong propensity towards stability, although this does not mean that they necessarily determine the behavior of the individual during adulthood (López, 2010; Rozenel, 2006; Schneider, 2006).

During early childhood, as a result of new cognitive-representative, communicative, social and psychomotor skills, and children enter a new phase in the development of attachment, known as "goal-corrected partnership". During this complex phase, which is characterized by conflict and the need for readaptation, changes occur which enable a greater diversity of behaviors. Thus, it has been observed that attachment behaviors are activated less frequently and with less intensity, since dyadic modulation patterns for ensuring emotional balance are well established; in other words, physical contact, while still necessary, gradually develops into psychological contact. The relationship is internalized and becomes representational. Children become more autonomous and emotionally self-regulating. The "moral self" emerges, reflected in children's ability to defer behavior, abide by rules and correct their behavior in the absence of the attachment figure.
Nevertheless, the most significant aspect of this new phase is that members of the attachment pair begin to operate in accordance with a set of shared plans and objectives, thus fostering a "closer, more intimate" relationship which "lays the groundwork for the development of more complex partner or social relations," which later extend to peer relations and relations with other significant adults (Cichetti, Cummings, Greenberg, \& Marvin, 1990; Eceiza, Ortiz, \& Apodaca, 2011; Thompson \& Meyer, 2007).

The mental model of the relationship is more elaborate and better adjusted to reality. Coupled with increased communicative skills, the cognitive changes that occur enable a more appropriate expression of demands, the communication of internal states and dialogue. Little by little, children begin to be able to infer the goals and understand the intentions, feelings and emotions of their attachment figure. These contents are all incorporated into this more complex structure, thus enabling children to operate internally both with their own perceptive and representation, and those of their attachment figure.

Based on the proposals forwarded by Bowlby, other authors (Bretherton, 2005; Cassidy, 1994; Geddes, 2010; Marvin \& Britner, 1999; Sroufe, 2000; Thompson, 1999) have made interesting contributions which have helped underscore the importance of the gradual emergence of models and their changes during early childhood. This is a particularly significant period for children's development and growth because it is during this time that certain components become consolidated as "scripts" or "knowledge structures". They also form the basis for the representation of past events and the psychological understanding of others, both are which are significantly associated with secure attachment with the mother (Arranz \& Oliva, 2010). As Bowlby points out, the greatest step forward is that representational models are now stored semantically.

Attachment during early childhood has been studied very little. Today, however, it is the subject of several interesting investigations, and according to Bowlby, there is still much to be discovered in this sphere. Focusing on this developmental pe- 
riod and the contextual changes associated with it, the continuity/discontinuity of attachment patterns and the contribution of fathers and their predictive power may provide some guidelines for exploring this stage in more detail. Nevertheless, while recognizing the consistency and tendency towards stability of the models established, it is accepted that attachment patterns are not immutable and may, in fact, be modified. In other words, they can be revised and/or restructured in light of other interpersonal relations and may change in response to major ecological shifts or developmental changes. Examples of this would be the acquisition of competences fostered by preoperational functioning and the achievement of formal operations, etc. (López, 2010; Schneider, 2006; Weinfield, Sroufe, \& Egeland, 2000). It has also been claimed that the attachment patterns proposed by Ainsworth may have little predictive power or be insufficient (Crittenden, 2002), and that changes occur, among other reasons, due to the potential developed in order to construct more precise representational models and more effective behavioral strategies. Based on this formulation, Bretherton and Munholland (1999), Bretherton, Ridgeway and Cassidy (1990), Cassidy (1988), Crittenden (1992), Lamb (1978, 2004), Main and Weston (1981) and Verschueren and Marcoen (1994) have developed new assessment procedures for early childhood, since "without methodological innovations it is highly unlikely that research will corroborate the stability of attachment any more conclusively than it has done so far" (Schneider, 2006: p. 27).

In consonance with these assertions, Verschueren and Marcoen (1999) found a low percentage of secure patterns in children in this age group from "intact" families. Their explanations are based on two arguments: 1) Firstly, they may reflect the influence of the assessment criteria of the Attachment Story Completion Task, which are stricter than those used in other tasks; 2) They may reflect the influence of the age factor. This explanation, which coincides with the findings of other research studies, is based on the low proportion of secure attachment patterns found in early childhood in comparison with the first three years of a child's life (33.9 \% in Cantero \& López, 2004; $42 \%$ in Cassidy, 1988; 55\% in Cohn, 1990; 34\% in Koeyer, 2001; 58\% in Shouldice \& Stevenson-Hinde, 1992; 26\% in Solomon, George \& De Jong, 1995; 60\% in Turner, 1993).

However, these findings do not provide any interpretation of the causes underlying the changes in manifestations of attachment. Verschueren and Marcoen (1999) ask two questions: 1) is there an increase in the risk of insecure attachment as children grow older and enter into a phase in which more difficulties may arise in the attachment relationship? This question has yet to be answered; And 2) could it be that, despite careful adaptations, attachment assessment measures are less valid in early childhood than in the first three years? This is another recurring question that remains, as yet, unanswered.

A final aspect which deserves to be highlighted is the fact that, although since the 1990s research into fatherhood has intensified, specific studies focusing on attachment with the father are still few and far between. Research mainly coincides in underscoring the father's role as "a secondary figure" and/or "a source of support or dependence for the mother", in accordance with. Indeed, little is known about the father's role. There is a consensus that while children do form attachment relationships with their father during the first year of life, they do so less than with their mother; there are therefore certain questions which have yet to be resolved (Fox, Kimmerly, \&
Schaffer, 1991). Based on a review of the literature, it seems logical to assume that the antecedents of attachment are different for fathers and mothers. Some results confirm this: certain individual paternal characteristics, such as the father's compliance with his accepted role, attitudes, the "central" status awarded fatherhood, etc. all predict the security of his relationship with his child better than the same factors for mothers (Bretherton, 2012; Cox, Owen, Henderson, \& Margand, 1992; Easterbrooks \& Goldberg, 1984; Horn, 2000; Howard, 2012; Lamb, 1978, 2004; Main \& Weston, 1981; Portu, 2011). This suggests that during early childhood, children construct separate representations of their attachment relationships with their father and mother (Verschueren \& Marcoen, 2005).

Following our review of the literature, the aim of this study was to explore and analyze attachment relationships on the basis of the representational models which children construct separately for their father and mother during early childhood. To this end, the following hypotheses were formulated: 1 ) the security of attachment established in relation to the mother is greater than that established in relation to the father; 2) a positive relationship exists between age and attachment security to fathers and mothers.

\section{Method}

\section{Participants}

The sample selected comprised 111 children ( 55 boys and 56 girls) from Irun (Autonomous Region of the Basque Country, Spain), aged between 3 years 9 months and 6 years 3 months. All were in either the $2^{\text {nd }}$ or $3^{\text {rd }}$ year of preschool. All the children in the sample were from "intact" two-parent families and had lived with both their parents from birth. Parents' consent was requested and received before the trials were administered.

\section{Measurement Instrument}

The "Attachment Story Completion Task" (Verschueren and Marcoen, 1994) was used in this study. The aim of this instrument is to assess participants' mental representation of themselves in relation to attachment to parents and the pattern of communication established, in children aged 3 to 6 . The most important difference between this measure and classification systems known as "Doll Play" (Bretherton; Ridgeway, \& Cassidy, 1990; Oppenheim, 1997; Page \& Bretherton, 2001) is that in this test, both the father and the mother are main characters in the stories, thus enabling "attachment styles" to be assessed individually for each parent.

Due to its methodological innovation and the fact that it has been used very little and is costly to apply and correct, as well as because it is the instrument used (for the first time in our sociocultural context) to measure representational models, we have provided a description of the task below.

- Medium used: A series of story stems are presented and narrated by the researcher using a set of dolls which represent a family in different circumstances. The child is asked to complete the story. Stories feature the father or the mother separately, and are presented in a counterbalanced order. The task consists of 5 stories, presented in the following order. Each story has its own theme and situation designed to activate attachment:

1. "The stolen bicycle": A youth he/she does not know steals the bicycle that the child's parents have given him/her (fear or 
external threat).

2. "The present": Upon arriving home from school, the child gives his/her parents a present that he/she made for them (a positive emotional interaction between the child/parent pair, based on a positive social signal emitted by the child).

3. "I'm sorry": The child says sorry for something he/she has done, and promises never to do it again (a threatening and stressful interaction).

4. "A fight at school": The child arrives home crying because he/she has had a fight at school (a threatening interaction).

5. "A monster in the bedroom": While asleep in bed one night, the child is woken up by a noise and thinks there is a monster in the room (fear or external threat).

- Assessment criteria: Each story ending given by participants is categorized as secure, secure/insecure or insecure and has its own scoring criteria, which are outlined below.

A secure response (4 or 5 points) is scored on the basis of the helpfulness, swiftness and responsiveness of parents' spontaneous response, happy ending to the story, any mention of positive sensations and a positive interaction between the parent/ child pair (care, consolation, assurance that the child is still loved, etc.).

A secure-insecure response (3 points) is scored on the basis of: not asking for help, absence of active engagement by parents, mention of only negative sensations (anger, physical punishment, etc.), feeling of not being loved, not feeling responsible for their actions, etc.

An insecure response ( 1 or 2 points) is when there is no interaction between the parent/child pair or when said interaction is negative.

- Scoring: Each story is scored on a 5-point scale and is coded separately, without any information being provided about the other stories. The maximum score (denoting security) is 25 (the sum of all stories), and the minimum score (denoting insecurity) is 5 .

\section{Psychometric Analysis of the Instrument}

Various analyses were carried out of the measurement in- strument used: the "Attachment Story Completion Task". Firstly, we should highlight the fact that both the application of the task itself and the collection of the children's responses during the individual interviews (with interrater agreement tests) were carried out with the utmost care and meticulousness. Rigorous qualitative studies were also conducted of the nature and scope of the responses given, the recordings and their transcriptions, in order to ensure a comprehensive understanding of their constructs.
Initially, several different analyses were conducted to eliminate any possible errors and verify the whole data recording process (analysis of the distribution models, dimensional scale analyses, construction of indexes for each variable, concurrent and discriminant validity, etc.), in order to guarantee that the information used for compiling the results was a faithful reflection of the subjects' responses. Having obtained the data matrix with all the necessary guarantees, the global scores for the instrument were compiled using statistical techniques such as the calculation of central tendency, dispersion and distribution coefficients. The reliability of the instrument was also analyzed using the Cronbach Alpha coefficient of internal consistency. The result was over the .70 threshold (fathers $=.78$ and mothers $=.74)$. The centered mean $(p=13.75 ; \mathrm{m}=14.41)$ and standard deviation $(p=4.49 ; \mathrm{m}=4.30)$ of the sum of the global indexes reflect good discriminatory potential. Rigorous qualitative studies of the nature and scope of the responses obtained guarantee that the information used is a faithful reflection of participants' responses.

Following the calculation of the global scores for the variable to be used, we employed bivariate descriptive and hypothesis testing techniques. In the latter case, in some instances nonparametric tests were used, such as the Kruskal-Wallis test, the Student "t" test for comparing two means and analyses of variance. For all these, version 17 of the SPSS application was used.

\section{Results}

\section{Representation of Attachment Relationships}

The order of the scores for the 5 stories on a scale from most to least secure, regardless of the order of presentation, was: "The present”, "I'm sorry”, “A fight at school”, “A monster in the bedroom" and "The stolen bicycle”. The stories featuring mothers scored higher for security of attachment than those featuring fathers (Table 1).

\section{Level of Attachment Security with Fathers and Mothers}

The differences between the means obtained: 13.75 with the father and 14.41 with the mother, are statistically significant, giving a t value $=-2.633$ and an associated probability of 0.010 , which is notably lower than the alpha reference level of 0.05 . We can therefore affirm that children scored significantly higher with the mother figure and their representations of secure attachment relationships with that figure were higher than with the father figure (Tables 2 and 3 ).

Table 1.

Means and total attachment percentages for the sample in all 5 stories.

\begin{tabular}{ccccc}
\hline & Mean & Mean & Percentage & Percentage \\
\hline The present & Father & Mother & Father & Mother \\
I'm sorry & 3.12 & $\mathbf{3 . 3 6}$ & 47.70 & 53.10 \\
A fight at school & 2.90 & $\mathbf{3 . 0 5}$ & 44.10 & 50.40 \\
A monster in the bedroom & 2.77 & $\mathbf{2 . 8 5}$ & 43.20 & 46.80 \\
The stolen bicycle & 2.55 & $\mathbf{2 . 6 3}$ & 28.80 & 34.20 \\
\hline
\end{tabular}


Table 2.

Statistics for related samples.

\begin{tabular}{ccccc}
\hline & M & N & SD & Standard error of the mean \\
\hline Global Attachment Father & $\mathbf{1 3 . 7 5}$ & 111 & 4.495 & .427 \\
Global Attachment Mother & $\mathbf{1 4 . 4 1}$ & 111 & 4.305 & .409 \\
\hline
\end{tabular}

Table 3.

Related sample test.

\begin{tabular}{|c|c|c|c|c|c|c|c|c|}
\hline & \multicolumn{5}{|c|}{ Related differences } & \multirow[t]{2}{*}{$\mathrm{t}$} & \multirow{2}{*}{ gl } & \multirow{2}{*}{ Sig. (bil) } \\
\hline & \multirow[t]{2}{*}{$\mathrm{M}$} & \multirow[t]{2}{*}{ SD } & \multirow[t]{2}{*}{$\begin{array}{l}\text { Standard error } \\
\text { of the mean }\end{array}$} & \multicolumn{2}{|c|}{$\begin{array}{l}\text { 95\% confidence interval } \\
\text { for the difference }\end{array}$} & & & \\
\hline & & & & Inf. & Sup. & & & \\
\hline $\begin{array}{l}\text { Global Attachment Father } \\
\text { Global Attachment Mother }\end{array}$ & -.67 & 2.667 & .253 & -1.17 & -.16 & -2.633 & 110 & .010 \\
\hline
\end{tabular}

\section{There Is a Positive Relationship between Age and Attachment Security to Fathers and Mothers}

Again, the degree of security constructed and consolidated with the mother figure is greater than that established with the father, although the results obtained in the different contexts differ substantially. The percentages of our study are higher as regards the security of attachment to parents, and are indeed more similar to those found in the first three years of a child's life than to those found most recently in early childhood in the European Community (Belgium and Holland). 45.03\% ( $n=50)$ of the children in our sample were found to have "insecure" relationships with their fathers, while $54.9 \%(n=61)$ had secure attachment. In the case of mothers, however, only $37.83 \%$ $(n=42)$ of the children had "insecure" attachment, while $62.15 \%$ ( $n=69)$ were "secure" in their relationship (Table 4).

Next, we analyzed the second element of the second hypothesis: the relationship between attachment and age. To this end, we divided the sample into two subgroups:

The Pearson correlations between the children's age (in years, months and weeks) and the global attachment scores (based on the differences found) were significant at a bilateral level of 0.01 (father $=.296$ and mother $=.305$ ). The results therefore reveal the existence of a relationship between children's age and the attachment they establish with their parents, with this attachment being appreciably stronger with the mother figure (Table 5).

Important differences are revealed here in accordance with age: the categories "very insecure" and "insecure" decrease notably between the ages of 5 and 6 , and this trend is inverted in the "secure" and "very secure" categories. In other words, the older the child, the greater the manifestation of security in the relationship they establish with their father (Table 6).

The same evolution was observed for attachment relationships with the mother figure as for attachment relationships with the father figure. Important differences were again revealed here in accordance with age. The categories "very insecure" and "insecure" were found to decrease notably, while the same inverted trend observed with fathers is again evident here in the "secure" and "very secure" categories, only at a higher level (Table 7).

In other words, the older the child, the greater the manifestation of security in the relationship they establish with their mother. Nevertheless, in this case, a statistically significant
(.29), direct and positive relationship is observed between age and security level. Younger children reveal more insecure representations, while older children reveal more secure ones. We can therefore confirm the existence of a "sensitive period" in the transition from the first three years of a child's life to early childhood, mainly in the relationship children establish with their mother.

\section{Discussion}

During early childhood, children's representational models are "more elaborate, sophisticated and precise", and contain psychological elements and a non-egocentric understanding of others, especially their primary attachment figure: their mother. Unlike in the first three years, the mother's status as primary attachment figure during early childhood is due more to her socially assigned role of carer than to any biological role she may play. These findings indicate that, by this phase, children have already developed a semantic representation and their models are more precise. This in turn suggests that they have already constructed separate models of their relationships and have different expectations regarding the behavior of their mother and their father. These results are consistent with those described by Bretherton, 2012; Cahill, Deater-Deckard, \& Pike, 2007; Crittenden, 2002; Thompson, 1999 and Verschueren and Marcoen, 2005.

In all stories, but especially in those which are more emotionally charged, mothers score higher in security, and their representations are characterized by a positive, close, intimate interaction based on accessibility, unconditional love and trust between the attachment figure and their child. This is especially evident in the stories "The present" and "I'm sorry". The same thing happens in the other stories also, in which the attachment-activating situations occur outside the attachment figure/ child interaction and depend on external agents. In our opinion, the responses obtained in the three last stories may reflect manifestations of the autonomy and independence acquired by the child due to the broadening of the contexts in which they are immersed (for example, the school context, which forces them to resolve problems by themselves), as well as to the different self-protection behaviors developed in response to the changes observed during this period. This may demonstrate the interaction between the attachment system and subjects' cognitive and social development, or alternatively, it may reflect the weaker 


\section{N. PORTU-ZAPIRAIN}

Table 4.

Comparison of security/insecurity level percentages during the first three years of life and early childhood.

\begin{tabular}{lcccc}
\hline & Secure & Insecure & Secure & Insecure \\
\hline First three years-Ainsworth, Blehar, Waters, \& Wall, 1978 & Mother & Mother & Father & Father \\
First three years -Main \& Weston, 1981; Lamb, 1978 & $\mathbf{6 5}$ & $\mathbf{3 5 ~ o r +}$ & & \\
Early childhood-Verschueren \& Marcoen, 1999 & $\mathbf{6 7 . 4}$ & $\mathbf{3 2 . 6}$ & $\mathbf{5 8 . 7}$ & $\mathbf{4 1 . 3}$ \\
Early childhood-Koeyer, 2001 & 44 & 56 & 48 & 52 \\
Early childhood-Portu, 2010 & 34 & 66 & 29 & 64 \\
\hline
\end{tabular}

Table 5.

Age of the children in years.

\begin{tabular}{ccc}
\hline & Frequency & Percentage \\
\hline $\mathbf{3}-\mathbf{4}$ & 51 & 45.9 \\
$\mathbf{5}-\mathbf{6}$ & 60 & 54.1 \\
Total & 111 & 100.0 \\
\hline
\end{tabular}

Table 6.

Contingency between Global Attachment Father and children’s age in years.

\begin{tabular}{ccccc}
\hline & & \multicolumn{2}{c}{ Child's age in years } & Total \\
\hline & & $\mathbf{3 - 4}$ & $\mathbf{5 - 6}$ & \\
& 1. Very insecure & 5 & 1 & 6 \\
Global Attachment Father & 2. Insecure & $\mathbf{9 . 8}$ & $\mathbf{1 . 7 \%}$ & $5.4 \%$ \\
& & 16 & 10 & 26 \\
& 3. Secure/Insecure & $\mathbf{3 1 . 4 \%}$ & $\mathbf{1 6 . 7 \%}$ & $23.4 \%$ \\
& & 16 & 20 & 36 \\
& 4. Secure & $\mathbf{3 1 . 4 \%}$ & $\mathbf{3 3 . 3 \%}$ & $32.4 \%$ \\
& & 11 & 22 & 33 \\
& 5. Very Secure & $\mathbf{2 1 . 6 \%}$ & $\mathbf{3 6 . 7 \%}$ & $29.7 \%$ \\
& & 3 & $\mathbf{7}$ & 10 \\
& & $\mathbf{5 . 9 \%}$ & $\mathbf{1 1 . 7 \%}$ & $9.0 \%$ \\
\hline
\end{tabular}

Table 7.

Contingency between Global Attachment Mother and children's age in years.

\begin{tabular}{ccccc}
\hline & & \multicolumn{2}{c}{ Child's age in years } & Total \\
\hline & & $3-4$ & $5-6$ & \\
& 1. Very Insecure & 5 & 0 & 5 \\
Global Attachment Mother & 2. Insecure & $\mathbf{9 . 8}$ & $\mathbf{0 \%}$ & $4.5 \%$ \\
& & 10 & 5 & 15 \\
& 3. Secure/Insecure & $\mathbf{1 9 . 6 \%}$ & $\mathbf{8 . 3 \%}$ & $13.5 \%$ \\
& & 22 & 26 & 48 \\
& 4. Secure & $\mathbf{4 3 . 1 \%}$ & $\mathbf{4 3 . 3 \%}$ & $43.2 \%$ \\
& & 11 & 20 & 31 \\
& 5. Very secure & $\mathbf{2 1 . 6 \%}$ & $\mathbf{3 3 . 3 \%}$ & $27.9 \%$ \\
& & 3 & 9 & 12 \\
& & $\mathbf{5 . 9 \%}$ & $\mathbf{1 5 . 0 \%}$ & $10.8 \%$ \\
\hline
\end{tabular}


discriminative power of these stories.

In our sociocultural context, levels of security of attachment during early childhood are similar (stable and/or continuous) to those found during the first three years of a child's life. However, some relevant and significant variations were found, with a "critical period" being identified in relation to age. There is a drop in the manifestation of security in children aged $3-4$ which, in our opinion, is due either to the contextual changes that occur at this age or to an increase in demands. On the other hand, children aged between 5 and 6 manifest higher levels of security. This result conflicts with those found by Verschueren and Marcoen (1999) and other authors, which prompts us to reflect on the different percentages obtained in different sociocultural contexts and with different child-rearing techniques.

Does security in the manifestation of attachment continue to increase as children grow older? In our study, the answer is yes. Does the "Attachment Story Completion Task" become less valid as children grow older, due to the cognitive-representational competence it involves? The statistical analyses conducted here indicate that it does not. Future research may wish to conduct longitudinal (rather than transversal) studies in order to analyze what happens in relation to the manifestation of security during the school-going years $(6-12)$. Our current lack of knowledge regarding this area constitutes a clear limitation and its study would help increase our knowledge of the development styles of attachment profiles and their level of security/insecurity. Also, the question of the instruments used and their validity in different developmental periods is a question that has yet to be resolved by future cross-cultural studies or meta-analyses.

\section{Acknowledgements}

Some of the data included in this paper are taken from the doctoral thesis presented by the author at the University of the Basque Country (UPV/EHU) on 6 November 2010, which received a unanimous Summa Cum Laude from the panel. The research project is being funded by the University of the Basque Country (UPV/EHU) within the framework of the NUPV $11 / 12$ project.

Nerea Portu Zapirain is a Tenured Professor at the Department of Psychology and Education at the University of the Basque Country. She holds a PhD in Psychology and her research focuses on attachment theory and the differential predictive power of fathers in different areas of development.

\section{REFERENCES}

Ainsworth, M. D. S. (1973). Some consideration regarding theory and Assessment relevant to attachments beyond infancy. In M. T. Greenberg, K. Cicchetti, \& E. M. Cummings (Eds.), Attachment in the preschool years: Theory, research and intervention (pp. 463-488). Chicago, IL: University of Chicago Press.

Ainsworth, M. D., Blehar, M. C., Waters, E., \& Wall, S. (1978). Patterns of attachment: A Psychological study of the strange situation. Hillsdale, NJ: Erlbaum.

Arranz, E., \& Oliva, A. (2010). Desarrollo psicológico en las nuevas estructuras familiares. Madrid: Pirámide.

Bowlby, J. (1969). Attachment and Loss. Vol. I Attachment. London: Hogarth Press.

Bowlby, J. (1980). Attachment and Loss. Vol III. Loss, sadness and depression. London: Hogarth Press.

Bretherton, I. (2005). In pursuit of the internal working model construct and it relevance to attachment relationship. In K. E. Grossmann, \& E.
Waters (Eds.), Attachment from infancy to adulthood. The major longitudinal studies (pp. 13-47). London: Guilford Press.

Bretherton, I. (2012). Fathers in attachment theory and research: A review. In L. A. Newland, H. S. Freeman, \& D. D. Coyl (Eds.), Emerging Topics on Father Attachment. Considerations in theory, context and development (pp. 24-33). New York: Routledge.

Bretherton, I., \& Munholland, K. A. (1999). Internal working models in Attachment Relationships: An construct revised. In J. Cassidy, \& P. R. Shaver (Eds.), Handbook of attachment: Theory, Research, and clinical applications (pp. 89-111). New York: The Guilford Press.

Breteherton, I., Ridgeway, D., \& Cassidy, J. (1990). Assessing internal working models of attachment relationships: An attachment story completion task for 3 years old. In M. T. Greenberg, D. Cicchetti, \& E. M. Cummings (Eds.), Attachment in the preschool years: Theory, research and intervention (pp.273-308). Chicago, IL: University of Chicago Press.

Cahill, K. R., Deater-Deckard, K., \& Pike, A. (2007). Theory of mind and the mother-child relationship. Social Development, 16, 45-56. doi:10.1111/j.1467-9507.2007.00371.x

Cantero, M. J., \& López, F. (2004). Factores predictores del periodo de adaptación escolar: La familia y las características de los menores cuando ingresan a los 3 años. Infancia y Aprendizaje, 27, 43-61. doi:10.1174/021037004772902097

Cassidy, J. (1988). Child-mother attachment and the self in six-year-old. Child Development, 59, 121-34. doi:10.2307/1130394

Cassidy, J. (1994). Emotion regulation: Influences on attachment relationships. Monographs of the Society for Research in Child Development, 59, 228-249. doi:10.2307/1166148

Ciccheti, D., Cummings, E. M., Greenberg, M. T., \& Marvin, R. (1990). An organizational perspective on attachment beyond infancy. In M. T. Greenberg, D. Cicchetti, \& E. M. Cummings (Eds.), Attachment in the preschool year: Theory, research and intervention (pp. 3-49). Chicago, IL: University of Chicago Press.

Cohn, D. A. (1990). Child-mother attachment of six-years-old and social competence at school. Child Development, 61, 152-162. doi:10.2307/1131055

Cox, M. J., Owen, M. T., Henderson, V. K., \& Margand, N. A. (1992). Prediction of infant-father and infant-mother attachment. Developmental Psychology, 28, 474-483. doi:10.1037/0012-1649.28.3.474

Crittenden, P. M. (1992). The quality of attachment in the preschool. Development and Psychopatology, 4, 209-241. doi:10.1017/S0954579400000110

Crittenden, P. M. (2002). Nuevas implicaciones clínicas de la teoría del apego. Valencia: Promolibro.

Easterbrooks, M. A., \& Goldberg, W. A. (1984). Toddler development in the family: Impact of father involvement and parenting characteristics. Child Development, 55, 740-752. doi:10.2307/1130126

Eceiza, A., Ortiz, M. J., \& Apodaca, P. (2011). Apego y afiliación: La seguridad del apego y las relaciones entre iguales en la infancia. Infancia y Aprendizaje, 34, 235-246. doi:10.1174/021037011795377610

Fox, N. A., Kimmerly, N. L., \& Schafer, W. D. (1991). Attachment to mother/attachment to father: A meta-analysis. Child Development, 62, 210-225.

Geddes, H. (2010). El apego en el aula. Relaciones entre las primeras experiencias infantiles, el bienestar emocional y el rendimiento escolar. Barcelona: Grao.

Horn, W. F. (2000). Fathering infants. In J. D. Osofsky, \& H. E. Fizgerald (Eds.), Handbook of infant mental health. Vol. III: Parenting and child care (pp. 270-297). New York: Wiley.

Howard, K. S. (2012). Paternal attachment, parenting beliefs and children's attachment. In L. A. Newland, H. S. Freeman, \& D. D. Coyl (Eds.), Emerging topics on father attachment. Considerations in theory, context and development (pp. 153-166). New York: Routledge.

Koeyer, E. L. (2001). Peer acceptance, parent-child fantasy play interactions, and subjective experience of the self-in-relation: A study of 4-to 5-year-old children. URL (last checked 12 April 2006). http://igitur-arcchive.library.nn.ul/dissertations/1965654//UU

Lamb, M. E. (1978). Qualitative aspects of mother and father-infant attachments. Infant Behavior and Development, 1, 265-275. doi:10.1016/S0163-6383(78)80038-1 


\section{N. PORTU-ZAPIRAIN}

Lamb, M. E. (2004). The role of father in child development. Nueva York: John Wiley and Sons.

López, F. (2010). Amores y desamores. Procesos de vinculación y desvinculación sexuales y afectivas. Madrid: Biblioteca Nueva.

Main, M., \& Weston, D. R. (1981). The quality of the toddler's relationship to mother and to father: Related to conflict behavior and the readiness to establish new relationships. Child Development, 52, 932940. doi:10.2307/1129097

Marvin, R. S., \& Britner, P. A. (1999). Normative development. The ontogeny of attachment. In J. Cassidy, \& P. R. Shaver (Eds.), Handbook of attachment: Theory, research, and clinical applications (pp. 44-67). New York: The Guilford Press.

Oppenheim, D. (1997). The attachment doll-play interview for preschoolers. International Journal of Behavioral Development, 20, 681-697. doi:10.1080/016502597385126

Page, T., \& Bretherton, I. (2001). Mother-and father-child attachment themes in the story completions of pre-schoolers from post-divorce families: Do they predict relationships with peers and teachers. Attachment \& Human Development, 3, 1-29.

Portu, N. (2011). El apego con el padre y la madre en la segunda infancia y su relación con la autoestima. Bilbao: UPV/EHU.

Rozenel, V. (2006). Los modelos operativos internos dentro de la Teoría del Apego. Aperturas psicoanalíticas. Revista Internacional de Psicoanálisis, 23, 1-26.

Schneider, B. H. (2006). Cuánta estabilidad en los estilos de apego está implícita en la teoría de Bowlby: Comentario al artículo de Félix López. Infancia y Aprendizaje, 29, 25-30.

Sroufe, L. A. (2000). Desarrollo emocional. La organización de la vida emocional en los primeros años. Oxford: University Press.

Thompson, R. A. (1999). Early attachment and later development. In J. Cassidy, \& P. R. Shaver (Eds.), Handbook of attachment: Theory, Research, and Clinical Applications (pp. 265-286). New York: The
Guilford Press.

Thompson, R. A. \& Meyer, S. (2007). The socialization of emotion regulation in the family. In J. Gross (Ed.), Handbook of emotion regulation (pp. 249-268). Nueva York: The Guilford Press.

Turner, P. J. (1993). Attachment to mother and behaviour with adults in preschool. British Journal of Developmental Psychology, 11, 75-89. doi:10.1111/j.2044-835X.1993.tb00589.X

Shouldice, A., \& Stevenson-Hinde, J. (1992). Coping with security distress: The separation anxiety test and attachment classification at 4.5 years. Journal of Child Psychology and Allied Disciplines, 33, 331348. doi:10.1111/j.1469-7610.1992.tb00870.x

Solomon, J., \& George, C. (1999) The measurement of attachment security in infancy and childhood. In J. Cassidy, \& P. R. Shaver (Eds.), Handbook of Attachment: Theory, Research, and Clinical Applications (pp. 287-318). New York: The Guilford Press.

Verschueren, K., \& Marcoen, A. (1994). Attachment story completion task classification system. Unpublished Manual, Belgium: University of Louvain.

Verschueren, K., \& Marcoen, A. (1999). Representation of self and socioemotional competence in kindergartners: Differential and combined effects of attachment to mother and to father. Child Development, 70, 183-201. doi:10.1111/1467-8624.00014

Verschueren, K., \& Marcoen, A. (2005). Perceived security of attachment to mother and father: Developmental differences and relations to elf-worth and peer relationships at school. In K. A. Kerns, \& R. A. Richardson (Eds.), Attachment in middle childhood (pp. 212-230). New York: The Guilford Press.

Weinfeld, N. S., Soufre L. A., \& Egeland, B. (2000). Attachment from infancy to early adulthood in a high-risk sample: Continuity, discontinuity, and their correlates. Child Development, 71, 695-702. doi:10.1111/1467-8624.00178 